\title{
Singapore 98
}

\author{
By Toh, Hai Leong
}

Fall 1998 Issue of KINEMA

th $A p r i l-2^{\text {nd }}$ May) started just before the closing of the more established 22nd Hong Kong International Film Festival on18th April. Big is the word for this year's festival and the 300 films shown is nearly twice the size of Hong Kong's output of 160 films.

Of course, more does not necessarily mean better. However, the Singapore festival this year did have an overwhelming number of entertaining features, avant garde feminist video works (Women About Women), a flood of South East Asian shorts and experimental films, seminar workshops with the proponents of the emerging Asian-American cinema, led by Chris Chan Lee (Yellow), Renee Tajima-Pena (My America ... Or Honk If You Love Buddha), lara Lee (Modulations), Jon Moritsugu (Fame Whore). There was a tribute to Cannes' 50th Anniversary with a slew of 15 French Golden Palm winners and a Wim Wenders' retrospective comprising 15 films. Homage was also paid to Thailand's Cherd Songsri with special focus on his country's cinema. This time the Festival Fringe held a screening of 33 shorts, mostly documentary. Not forgotten were the American independent films and Canadian films, one of which was Clement Vigo's memorable The Planet of Junior Brown as well as the usual array of notable World and Asian films.

While the prestigious Hong Kong festival seems to have waned somewhat in quantity and quality, its Singapore counterpart has continued on an aggressively eclectic path which has been rewarded with good attendances for the major Asian and international films. Film-going crowds have never had it so good: the festival opened with Japanese filmmaker Takeshi Kitano's Hana-bi (Fireworks), winner of the Golden Lion in Venice last year and closed with maverick Hong Kong director Wong Kar-wai's Happy Together, a film about a gay relationship which won last year's Best Director award in Cannes.

The festival has its share of glamour too, with the likes of Winston Chao and Yang Kuei- mei ( $A$ Little Life Opera by Allen Fong), Hollywood's Casper Van Dien (the new Tarzan), Hong Kong's E-kin Cheng and Jordan Chan, both from the highly popular Young and Dangerous series, cinematographer Chris Doyle, director Stanley Kwan (Rouge) to give glossy credence and keep starry-eyed film fans entranced.

The festival atmosphere this year is one of experimentalism: an uneasy mix of classic Asian and European "art-house" films with brilliant debuts made by young directors like Park Ki-yong (Motel Cactus), Chang Waihung (After The Crescent), Pen-ek Ratanaruang (Fun Bar Karaoke) and Nonzee Nimibutr (Dang Bireley's And Young Gangsters). Like Wenders' cult film, State of Things which was completely over-run, the most sought-after film in this group was Zhang Yuan's East Palace, West Palace (1996).

Banned by the Chinese authorities for its gay subject matter, this highly controversial, "guerrilla-made" film premiered at the1st Pusan International Film Festival in 1996. Zhang Yuan's lyrical scenes of a traditional opera about a female prisoner's love for her executioner are juxtaposed with the contemporary story of a gay writer who gets nabbed during a police raid and who expresses his love for the interrogating police officer. At its heart is the relationship between power and sex as well as an examination of a Confucianistic society's uneasy fascination when it comes to confronting the issues posed by a "subversive" lifestyle.

Likewise, Wong's Happy Together, starring Leslie Cheung and Tony Leung Chi-wai, is not about homosexuality per se but a diverting study of a relationship which may as well have been between a man and a woman. Here, the film focuses on two men in a relationship in which one partner is more committed than the other. It is the eternal problem of one loving too much, and the other too little with no hope of the two sides meeting.

Another type of obsession is seen in Jogho by director U-wei bin Hajisaari who is Malaysia's one-man New Wave institution. The film tells the story of a bull-trainer Mamat who thinks of nothing but his prized bull even when he is incarcerated for suspected collusion to murder his rivals Isa and Dolah who initiate a cycle of murder, retaliation and retribution.

The Godardian proclamation, "All films are about death at work..." was never more true than in the unassuming, yet monumental work by Korean director Byun Young-joo. Habitual Sadness is about old Granny 
Kang, a gifted painter who, with the rest of her elderly ex-comfort women colleagues, were forced into serving the Japanese soldiers during World War II. The film shows how they live a dignified, independent life in the serenity of the country, tending to vegetable gardens and chicken farms to be self-sufficient. Some stories of the evil and unspeakable injustice done to them are inevitably told. For example the straight-forward narrative by Granny Shim Mi-ja, 74, who relates the terrifying sight of women (Korean and other Asian nationalities forcefully recruited for sex) who contracted syphilis from repeated rapes by the ravenous Japanese soldiers.

Despite the diversity of films, certain themes surfaced time and again: obsession bordering on the pathological ( Aoyama Shinji's An Obsession); warped, misguided love (Nobuhiro Suwa's 2 Duo); the power of evil (Takahisa Zeze's Kokkuri, János Szasz's The Witman Boys); creative and destructive impulses (Youssef Chahine's Destiny); painful memories and guilt (Park Ki-yong's Motel Cactus, Liv Ullman's Private Confessions); the issue of violence (Nicolas Winding Refn's Pusher, Nonzee Nimibutr's Dang Bireley's And Young Gangsters); and small narratives told simply, without embellishment or rancour, most notably in Abbas Kiarostami's The Taste of Cherries (last year's Cannes joint winner of the Palme d'Or), about the journey by car of a despairing man who wants to kill himself but needs someone willing to bury his body

One of the most memorable films was Western, directed by Frenchman Manual Poirer, a bitter-sweet road movie set in Brittany about two characters -- a handsome Spaniard and a Russian immigrant who aspires to be a womanizer who are thrown together by fate, each looking for love and a place called home.

Another gem was the Iranian neo-realist homage to de Sica's Bicycle Thief, Majid Majidi's Children of the Heaven. Having lost his younger sister's shoes, Ali hits on the idea of sharing his pair of tattered shoes with her, a solution which leads to other complications. The film won the Silver Screen award for Best Film at the Singapore International Film Festival this year.

The coup of the film festival, however, was the introduction of a new wave of Asian-American documentary and feature filmmaking, led by Renee Tajima-Pena, Chris Chan Lee, Jon Moritsugu, Iara Lee and Eric Koyanagi. Their works reflect a relatively young and adventurous sensibility that is both penetrating and affable. Like his Hong Kong counterpart, Philip Cheah has steadily been gaining respect and recognition as the Singapore International Film Festival's programme director, a reputation which will surely be enhanced by the inauguration of Asian-American cinema in the Asia-Pacific region.

Of considerable charm is the flawed road movie, Hishamuddin Rais' From Jemapoh to Manchestee, two and a half years in the making, boasting brilliant cinematography and at times inspired direction but the pacing is a little laboured (for a film on the move and apparently going somewhere) and the casting of the two leads (who look more urban than rural) a little wanting.

On the other hand, its Taiwanese counterpart, Ho Ping's Wolves Cry Under The Moon is a near masterpiece described by one critic as the "ultimate road movie" in Taiwanese cinema. In this captivating story with the intelligence but not the angst of Wim Wenders' King of the Road (also shown at the Goethe Institut), various characters take to the road, converging at the film's end: an injured hired gunman (Tuo Chong-hwa) hijacks a bus and holds the driver hostage; an unhappy driver of a company's president takes the staff car out for his own pleasure; a woman takes off with a man's vehicle and holds an amusing mobile phone conversation with the incensed owner who later becomes besotted with her.

Taiwan's working and middle-classes now increasingly affluent, are the subject for parody, satire and serious treatment in three very different films. Wang Shaudi's Yours and Mine pokes fun at bourgeois citizens fighting over car parking space, displaying uncivil behaviour in high-rise apartments and a host of unhealthy urban habits. Chen Yu-hsuan's Love Go Go is about two unattractive protagonists who long for love while Lin Cheng-sheng 's Murmur of Youth looks at the lesbian relationship between two cinema ticket sellers which develops as a result of loneliness and an uncertain future.

Ironically, the local surprise box-office hit this year has been the highly entertaining satirical comedy called Money No Enough, a true-blue Singaporean feature about three friends who are always in financial straits. The film stars Jack Neo who also scripted the movie which is about 85 percent in the Hokkien vernacular. Money will prove, at a later date, if not now, to be a local landmark comedy well worth its admission price of SGD 8.24. 
Jack Neo also won the festival's Silver Screen award for Best Director for his 9-minute short, Replacement Killers (not to be confused by Antoine Fuqua's film of the same title starring Hong Kong actor Chow Yun-fat), about how hired killers are engaged.

\section{Author Information}

TOH Hai Leong is a Singapore-based freelance film critic and filmmaker (Zombie Dogs, 2005) who writes for independent film publications such as Screen International and World Paper. He has covered the Hong Kong International Film Festival since 1985 and specializes in the cinemas of Hong Kong, Taiwan, China, Korea and Japan. 